International Journal of Engineering \& Technology, $7(4.33)(2018) 114-118$
International Journal of Engineering \& Technology
SPC
Website: www.sciencepubco.com/index.php/IJET
Research paper

\title{
Survey on Environmental Care among UiTM Campus Tapah Student on Solid Waste Management using Mean Score and t-Test Analysis
}

\author{
Nurul Husna Jamian", Faridah Zulkipli ${ }^{1}$, Ilya Zulaikha Zulkifli' ${ }^{1}$, Zulkifli Mohd Nopiah² \\ ${ }^{I}$ Faculty of Computer and Mathematical Sciences, Universiti Teknologi MARA, Perak Branch, Tapah Campus, Tapah Road, \\ 35400 Perak, Malaysia \\ ${ }^{2}$ Faculty of Engineering and Built Environment, Universiti Kebangsaan Malaysia, UKM Bangi, 43600 Selangor, Malaysia \\ *Corresponding author E-mail: nurul872@perak.uitm.edu.my
}

\begin{abstract}
The study is focusing on the environmental care components in solid waste management among students at UiTM Campus Tapah. This study is conducted through a questionnaire and involved a total of 354 students. The environment care components are consisting of knowledge, practice, attitude, perception and awareness. Statistical analysis of mean score and t-test are conducted in order to analyze the data collected. The results of the survey are highlighted that majority of the UiTM Tapah students had high knowledge level towards environmental care; and had very good practice in environment cleanliness; had a moderate concern on attitude, and the majority of the students had moderate perception in term of understanding and practicing solid waste separation and finally majority of students know their personal accountability towards environment care based on awareness component. As a conclusion, environmental care among students shows positive responses in Awareness, Practice, Attitude, Knowledge and Perception towards sustainable solid waste management in future.
\end{abstract}

Keywords: Solid Waste Management; Environmental Care; Mean Score Analysis; $t$-Test Analysis.

\section{Introduction}

Solid waste management is a complex and important issue worldwide. The increasing trend in waste generation annually gives an impact towards sustainability of the environment. These due to changes in life styles, income level, urbanization process and increment in the population rate [1-2]. The waste generation rises approximately three to four percent every year based on the population rate. Over the past two decades the increased generation of solid waste has been reported not only in Malaysia but also worldwide with many ascribing it to industrialization. Since Malaysia is a multi-ethnic, multi-cultural society and well-endowed with natural resources in areas such as agriculture, forestry, and minerals which influence the generation characteristics of Malaysia Municipal Solid Waste [3]. In 2015, the waste generation was 38563 tonne/day and in 2017, the waste generation increase to 42672 tonne/day. It expected to continuously increase to 44888 tonne/day in 2018. Based on the forecast value, in 2020 the waste generated will tremendously rise 49670 tonne/day with 5.19 percent increase from 2015 to 2020 [4]. This issue motivates researcher to investigate further. Thus, this study is purposely conducted to determine the level of knowledge, practice, attitude, perception and awareness on environmental care are vital. The results are significantly impact on the achievement on sustainable solid waste management in future. This study applies mean score and t-test to analyze the data collected among undergraduate students at UiTM Campus Tapah. The finding will be used to improve and strengthen the program of community mind transformation program by measuring the level of environmental care components.

\section{Literature Review}

Survey results in 2011, the Solid Waste Management and Public Cleansing Corporation (SWCorp) have identified 241 solid waste locations in states that adopt the Solid Waste Management and Public Cleansing Act 2007 which are Perlis, Kedah, Kelantan, Terengganu, Pahang, Federal Territory Kuala Lumpur and Putrajaya, Negeri Sembilan, Malacca and Johor. Thus, SWCorp has run a solid waste monitoring effort and the implementation of awareness campaigns. In addition, various improvements have also been made to ensure that the amount of waste disposal sites can be minimized and non-recurring. By the end of December 2013, monitoring found that there were still 95 active junk or active hotspot [5]. This can illustrate that the perception of society is still low on the culture of hygiene and the culture of dumping junk is still a practice of Malaysian society. As the issue of hygienic sanitation and solid waste management in Malaysia is growing and tedious, there is a need to create a more responsible and caring society on hygiene culture.

There are studies that concern on environment care or cleanliness regarding to knowledge, practice, attitude, perception and awareness. A study by [6] revealed that Malaysian has high knowledge meanwhile moderate awareness and practices on cleanliness. Then, a study by [7] covers Kuala Lumpur and Pulau Pinang reported that level of knowledge among society in Malaysia 
varies regarding to particular environmental issues. It found that society had high knowledge of natural disaster. In addition, Malaysia had temperate level of knowledge on recycling program and energy source renewal. However, they had low level of knowledge on air and noise pollution. It summarized that attitude of the public towards the environment and its preservation efforts are relatively low.

Another study by [8] among residents of Choma township of Southern Zambia mentioned that respondents had a bad attitude and perceptions towards Solid Waste Management (SWM) resulting into indiscriminate dumping. It caused by lack of education program and proper solid waste management services in the area. The study also identified that society had low responsibility on keeping public places clean where they did not perceive that their disposal practice contributed to the littering of the environment. The findings further showed that residents were did not notice their role in SWM apart from keeping their homes clean. Besides, it discovered that a good engagement between community leaders and establishment of the baseline data for an environmental health was an important way of offering environmental education (EE). This study also concluded that it was concluded that people's negative perceptions and lack of a proper system for waste collection negatively affected the situation in the area, and that EE was needed to help people understand their roles and effects of their careless dumping.

Therefore, a knowledge, attitude and behavior towards environmental model in [7,9] stated that environment education will help to raise awareness and attitude as the ultimate goal to produce a generation with positive behavior towards environmental care where there is linear correlation among knowledge, awareness, attitude and behavior towards environmental care as figure out in Knowledge, Attitude and Behavior towards Environmental Model as shown in the Fig. 1.

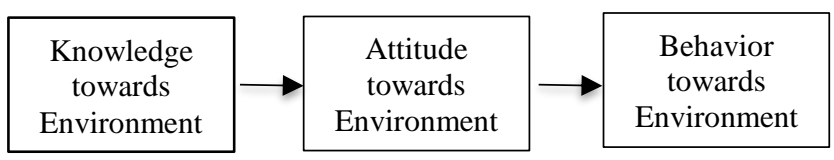

Fig. 1: Knowledge, Attitude, Behavior towards Environmental Model

\section{Methodology}

This study sought to assess the level of knowledge, practice, attitude, perception and awareness among students from Universiti Teknologi Mara (UiTM), Perak Branch, Tapah Campus towards environmental care. A total of 354 students were selected conveniently as a sample of study from different program in Faculty of Computer and Mathematical Sciences (FSKM). This technique used concerned on the respondents' eligibility, pleased, and available at the right time and without pressure from any program and part [12]. A primary data collected and conducted through a direct questionnaire adopted from [7, 13]. In this study, the questionnaires structure divided into six parts as summarized in Table 1.

Table 1: Parts and variables of study instruments

\begin{tabular}{l}
\multicolumn{1}{|c|}{ Table 1: Parts and variables of study instruments } \\
\begin{tabular}{|c|l|}
\hline Part & \multicolumn{1}{c|}{ Variable } \\
\hline A & Respondents' background \\
\hline B & $\begin{array}{l}\text { Level of respondents' knowledge regarding to environmental } \\
\text { Care }\end{array}$ \\
\hline C & Level of respondents' practice regarding to environmental Care \\
\hline D & Level of respondents' attitude regarding to environmental Care \\
\hline E & Level of respondents' perception regarding to environmental Care \\
\hline F & Level of respondents' awareness regarding to environmental Care \\
\hline
\end{tabular}
\end{tabular}

In analysis section, score mean was calculated by multiplying the frequency with the score point for each item within five variables from Part B to Part F using Microsoft Excel 2013 in order to measure the level of knowledge, practice, attitude, perception and awareness by categorizing using the Parallelity Level as shown in Table 2 [6].

Table 2: Parallelity Level

\begin{tabular}{|c|c|}
\hline Mean Score Range & Parallelity Level \\
\hline $3.68-5.00$ & High \\
\hline $2.34-3.67$ & Moderate \\
\hline $1.00-2.33$ & Low \\
\hline
\end{tabular}

Furthermore, t-test analysis is executed using IBM SPSS version 22 to see the significant difference in gender on knowledge, practice, attitude, perception and awareness level [6]. There are two competing hypotheses such as the null hypothesis $\left(\mathrm{H}_{0}\right)$ and the alternative hypothesis $\left(\mathrm{H}_{1}\right)$. In this study the hypotheses stated as follow:

$\mathrm{H}_{0}$ : There is no difference of knowledge, practice, attitude, perception and awareness of environmental care based on gender. $\mathrm{H}_{1}$ : There is a difference of knowledge, practice, attitude, perception and awareness of environmental care based on gender.

The $\mathrm{H}_{0}$ will be rejected if $\mathrm{p}$-value $\leq$ significant value $(\alpha)=0.05$. It means that there was a significant mean difference between knowledge, practice, attitude, perception and awareness of environmental care based on gender and vice versa [6, 10-11].

\section{Results and Discussion}

\subsection{Mean Score Analysis}

\subsubsection{Mean Score of Knowledge Level towards Environmental Care}

There are five questions about level of knowledge on environmental care. The questions are related to the student's knowledge towards environmental care such as the effects of flash floods caused by the disposal of waste into drains or drainage, the transmission of diseases caused by poor environment care and the benefits of personal and public hygiene practice. Based on the score mean values as shown in Table 3 , it found that majority of the UiTM Tapah students had high knowledge towards environmental care regarding to Table 2 [6]. It means that students have a good understanding of solid waste management, cleanliness, and public hygiene.

\subsubsection{Mean Score of Practice towards Environmental Care}

This study consists of five items to identify the level of practice towards environmental care among the students as shown in Table 4. The mean score also calculated and categorized using the parallelity level as shown in Table 2 [6]. Based on the score mean, it found that students had very good (high) practice in environment cleanliness meanwhile they had moderate practice in spending money, choose and usage on eco-friendly products, and will always practice and encourage hygiene practices among friends and family as their routine and daily necessities that contributes on environmental care.

\subsubsection{Mean Score of Attitude towards Environmental Care}

According to attitude level, there are three items considered to know the students' behavior towards environmental care. Referring to parallelity in Table 2 [6], the score mean value revealed that students had high concern for cleanliness environment in order to live healthy and 3R (Reduce, Reuse, Recycle) practice. Despite they had moderate attitude on avoiding plastic bag usage during shopping. 


\subsubsection{Mean Score of Perception towards Environmental Care}

Based on Table 6, the perception level is measured using three items as well towards knowledge, concept and practice in solid waste management/separation. Based on parallelity level as in Table 1 by [6], this study found that majority of the students had moderate perceptions in terms of understanding and practicing solid waste separation.

\subsubsection{Mean Score of Awareness towards Environmental Care}

Table 7 shows the score mean of awareness level among students towards environmental care. This study interested to know whether students had self-awareness that they are responsible for the environment and not put this issue on the government side. It found that majority of students know their personal accountability towards environment care. But, they were moderately aware to be volunteers to solve environmental hygiene problems.

Table 3: Score Mean of Knowledge Level among Students towards Environmental Care

\begin{tabular}{|c|c|c|c|c|c|c|c|}
\hline Items in Part B & $\begin{array}{c}\text { Strongly } \\
\text { Disagree } \\
(1)\end{array}$ & $\begin{array}{l}\text { Disagree } \\
\text { (2) }\end{array}$ & $\begin{array}{l}\text { Not Sure } \\
\text { (3) }\end{array}$ & $\begin{array}{l}\text { Agree } \\
(4)\end{array}$ & $\begin{array}{c}\text { Strongly } \\
\text { Agree } \\
(5)\end{array}$ & $\begin{array}{l}\text { Score } \\
\text { Mean }\end{array}$ & Level \\
\hline $\begin{array}{l}\text { 1. Removing trash into the drains can cause flash } \\
\text { floods. }\end{array}$ & 3 & 3 & 21 & 139 & 188 & 4.43 & High \\
\hline $\begin{array}{l}\text { 2. Society are more respectful to people who are care } \\
\text { of cleanliness. }\end{array}$ & 0 & 1 & 23 & 139 & 191 & 4.47 & High \\
\hline $\begin{array}{l}\text { 3. The action of removing any waste will affect the } \\
\text { environment }\end{array}$ & 0 & 0 & 0 & 93 & 261 & 4.74 & High \\
\hline $\begin{array}{l}\text { 4. Keeping environmental cleanliness is everyone's } \\
\text { responsibility }\end{array}$ & 0 & 0 & 4 & 88 & 262 & 4.73 & High \\
\hline $\begin{array}{ll}\text { 5. } & \begin{array}{l}\text { Environmental hygiene can prevent disease } \\
\text { transmission }\end{array}\end{array}$ & 0 & 0 & 5 & 100 & 249 & 4.69 & High \\
\hline
\end{tabular}

Table 4: Score Mean of Practice Level among Students towards Environmental Care

\begin{tabular}{|c|c|c|c|c|c|c|c|}
\hline Items in Part C & $\begin{array}{c}\text { Strongly } \\
\text { Disagree } \\
\text { (1) }\end{array}$ & $\begin{array}{c}\text { Disagree } \\
(2)\end{array}$ & $\begin{array}{l}\text { Not Sure } \\
\text { (3) }\end{array}$ & $\begin{array}{c}\text { Agree } \\
(4) \\
\end{array}$ & $\begin{array}{c}\text { Strongly } \\
\text { Agree } \\
(5)\end{array}$ & $\begin{array}{l}\text { Score } \\
\text { Mean }\end{array}$ & Level \\
\hline $\begin{array}{l}\text { 1. I believe that I can contribute to better environment } \\
\text { of cleanliness }\end{array}$ & 1 & 0 & 50 & 233 & 70 & 4.05 & High \\
\hline $\begin{array}{l}\text { 2. I am willing to spend more on environmental } \\
\text { friendly products }\end{array}$ & 5 & 28 & 193 & 116 & 12 & 3.29 & Moderate \\
\hline 3. I use eco-friendly products & 3 & 19 & 167 & 153 & 12 & 3.43 & Moderate \\
\hline $\begin{array}{l}\text { 4. I implement hygiene practices among my friends } \\
\text { and family members }\end{array}$ & 1 & 5 & 5 & 219 & 79 & 3.66 & Moderate \\
\hline $\begin{array}{l}\text { 5. I choose daily necessities that I think are good for } \\
\text { the environment }\end{array}$ & 2 & 21 & 146 & 163 & 22 & 3.51 & Moderate \\
\hline
\end{tabular}

Table 5: Score Mean of Attitude Level among Students towards Environmental Care

\begin{tabular}{|c|c|c|c|c|c|c|c|}
\hline Items in Part D & $\begin{array}{c}\text { Strongly } \\
\text { Disagree } \\
(1)\end{array}$ & $\begin{array}{c}\text { Disagree } \\
\text { (2) }\end{array}$ & $\begin{array}{c}\text { Not Sure } \\
\text { (3) }\end{array}$ & $\begin{array}{l}\text { Agree } \\
(4) \\
\end{array}$ & $\begin{array}{l}\text { Strongly } \\
\text { Agree } \\
(5)\end{array}$ & $\begin{array}{l}\text { Score } \\
\text { Mean }\end{array}$ & Level \\
\hline $\begin{array}{l}\text { 1. I know about the diseases that can be caused by a } \\
\text { dirty environment } \\
\text { 2. I realize dirty environment that may cause diseases. }\end{array}$ & 0 & 8 & 79 & 205 & 62 & 3.91 & High \\
\hline 3. I know about 3R Practice & 2 & 11 & 117 & 193 & 31 & 3.68 & High \\
\hline 4. I avoid to use a lot of plastic bags when shopping & 6 & 49 & 120 & 148 & 31 & 3.42 & Moderate \\
\hline
\end{tabular}

Table 6: Score Mean of Perception Level among Students towards Environmental Care

\begin{tabular}{|c|c|c|c|c|c|c|c|}
\hline Items in Part E & $\begin{array}{c}\text { Strongly } \\
\text { Disagree } \\
(1)\end{array}$ & $\begin{array}{c}\text { Disagree } \\
\text { (2) }\end{array}$ & $\begin{array}{l}\text { Not Sure } \\
\text { (3) }\end{array}$ & $\begin{array}{c}\text { Agree } \\
\text { (4) } \\
\end{array}$ & $\begin{array}{c}\text { Strongly } \\
\text { Agree } \\
(5)\end{array}$ & $\begin{array}{l}\text { Score } \\
\text { Mean }\end{array}$ & Level \\
\hline $\begin{array}{l}\text { 1. I certain about the policy of solid waste separation } \\
\text { at sources. }\end{array}$ & 11 & 33 & 157 & 134 & 19 & 3.33 & Moderate \\
\hline $\begin{array}{l}\text { 2. I understand the concept of solid waste separation } \\
\text { at the sources }\end{array}$ & 5 & 30 & 137 & 163 & 19 & 3.45 & Moderate \\
\hline $\begin{array}{l}\text { 3. I agree with the solid waste separation at the } \\
\text { sources. }\end{array}$ & 11 & 49 & 169 & 109 & 16 & 3.20 & Moderate \\
\hline
\end{tabular}

Table 7: Score Mean of Awareness Level among Students towards Environmental Care

\begin{tabular}{|c|c|c|c|c|c|c|c|}
\hline Items in Part E & $\begin{array}{c}\text { Strongly } \\
\text { Disagree } \\
\text { (1) }\end{array}$ & $\begin{array}{c}\text { Disagree } \\
\text { (2) }\end{array}$ & $\begin{array}{l}\text { Not Sure } \\
\text { (3) }\end{array}$ & $\begin{array}{c}\text { Agree } \\
\text { (4) }\end{array}$ & $\begin{array}{l}\text { Strongly } \\
\text { Agree } \\
(5)\end{array}$ & $\begin{array}{l}\text { Score } \\
\text { Mean }\end{array}$ & Level \\
\hline $\begin{array}{l}\text { 1. Keeping environmental cleanliness is everyone's } \\
\text { responsibility. }\end{array}$ & 3 & 9 & 26 & 174 & 142 & 4.25 & High \\
\hline $\begin{array}{ll}\text { 2. } & \begin{array}{l}\text { Keeping environmental hygiene is easy for } \\
\text { everyone. }\end{array}\end{array}$ & 0 & 6 & 21 & 170 & 157 & 4.35 & High \\
\hline $\begin{array}{l}\text { 3. I always volunteer to solve any environmental } \\
\text { issues. }\end{array}$ & 49 & 137 & 91 & 63 & 14 & 2.59 & Moderate \\
\hline
\end{tabular}

\subsection{Correlation Analysis}

Based on Table 8, there was a positive and significant relationship among knowledge and practice $(\mathrm{r}=0.218, \mathrm{p}<0.01)$, attitude $(\mathrm{r}=0.148, \mathrm{p}<0.01)$ and awareness $(\mathrm{r}=0.216, \mathrm{p}<0.01)$. It also found that there was a positive and significant relationship among practice and attitude $(r=0.462, \mathrm{p}<0.01)$ also perception $(\mathrm{r}=0.262$, $\mathrm{p}<0.01)$. Besides that, relationship between attitude and perception $(r=0.290, p<0.01)$ together with awareness $(r=0.228, p<0.01)$ also shows a positive and significant relationship. Furthermore, 
there was no relationship between knowledge and perception $(\mathrm{r}=$ $0.012, p>0.01)$, practice and awareness $(r=0.101, p>0.01)$ and perception and awareness $(r=0.014, p>0.01)$. This shows that when a person has knowledge, they are not necessarily having a good perception towards environmental care. Besides that, when a person goods in practicing the environmental care, they are not good in awareness of it. Sometimes, they are practicing it because of the rules forcing them. Besides that, perception towards environmental care does not influence of an individual consciousness in environmental care.

Table 8: Correlations of Knowledge, Practice, Attitude, Perception and Awareness Level towards Environmental Care

\begin{tabular}{|c|c|c|c|c|c|c|}
\hline & & Knowledge & Practice & Attitude & Perception & Awareness \\
\hline \multirow[t]{3}{*}{ Knowledge } & Pearson Correlation & 1 & $.218^{* *}$ & $.148^{* *}$ & .012 & $.216^{* *}$ \\
\hline & Sig. (2-tailed) & & .000 & .005 & .828 & .000 \\
\hline & $\mathrm{N}$ & 354 & 354 & 354 & 354 & 354 \\
\hline \multirow[t]{3}{*}{ Practice } & Pearson Correlation & $.218^{* *}$ & 1 & $.462^{\text {** }}$ & $.262^{* * *}$ & .101 \\
\hline & Sig. (2-tailed) & .000 & & .000 & .000 & .059 \\
\hline & $\mathrm{N}$ & 354 & 354 & 354 & 354 & 354 \\
\hline \multirow[t]{3}{*}{ Attitude } & Pearson Correlation & $.148^{* *}$ & $.462^{* *}$ & 1 & $.290^{* *}$ & $.228^{* *}$ \\
\hline & Sig. (2-tailed) & .005 & .000 & & .000 & .000 \\
\hline & $\mathrm{N}$ & 354 & 354 & 354 & 354 & 354 \\
\hline \multirow[t]{3}{*}{ Perception } & Pearson Correlation & .012 & $.262^{* *}$ & $.290^{* * *}$ & 1 & .014 \\
\hline & Sig. (2-tailed) & .828 & .000 & .000 & & .793 \\
\hline & $\mathrm{N}$ & 354 & 354 & 354 & 354 & 354 \\
\hline \multirow[t]{3}{*}{ Awareness } & Pearson Correlation & $.216^{* *}$ & .101 & $.228^{* *}$ & .014 & 1 \\
\hline & Sig. (2-tailed) & .000 & .059 & .000 & .793 & \\
\hline & $\mathrm{N}$ & 354 & 354 & 354 & 354 & 354 \\
\hline
\end{tabular}

\section{3. t-Tests Analysis}

In this section, this study intends to identify the differences in knowledge, practice, attitude, perception and awareness of environmental care based on gender. Thus t-Test analysis had been carried out to get the findings. According to the results in Table 9, it found that there is no significant difference in gender for knowledge and perception towards environmental care but we can see the differences in gender for practice, attitude and awareness.
Based on $\mathrm{t}$ test results for knowledge $(\mathrm{t}=-1.015, \mathrm{df}=352, \mathrm{p}>0.05)$ and perception $(\mathrm{t}=-1.442, \mathrm{df}=352, \mathrm{p}>0.05)$ it shows that there is no significant difference between male and female in knowledge of environmental care. In contrast for practice $(t=-4.591, d f=352, p$ $<0.05)$, attitude $(\mathrm{t}=-2.106, \mathrm{df}=352, \mathrm{p}<0.05)$ and awareness $(\mathrm{t}=$ - 2.238, $\mathrm{df}=352, \mathrm{p}<0.05)$ of environmental care, it shows that there is significant difference between male and female. Then according to the mean values, it found that female had higher level of practice, attitude and awareness.

Table 9: t-Test for Environmental Care Component by Gender

\begin{tabular}{|c|c|c|c|c|c|c|}
\hline Gender & $\mathrm{N}$ & Mean & Standard Deviation & $\mathrm{t}$ & $\mathrm{df}$ & $\mathrm{p}$ \\
\hline \multicolumn{7}{|l|}{ 1. Knowledge } \\
\hline Male & 112 & 4.5821 & 0.3914 & -1.015 & 352 & 0.311 \\
\hline Female & 242 & 4.6240 & 0.3456 & & & \\
\hline \multicolumn{7}{|l|}{ Practice } \\
\hline Male & 112 & 3.5089 & 0.4711 & -4.591 & 352 & $0.000^{*}$ \\
\hline Female & 242 & 3.7372 & 0.4175 & & & \\
\hline \multicolumn{7}{|l|}{ 3. $\quad$ Attitude } \\
\hline Male & 112 & 3.5804 & 0.5743 & -2.106 & 352 & $0.036^{*}$ \\
\hline Female & 242 & 3.7094 & 0.5176 & & & \\
\hline \multicolumn{7}{|l|}{ 4. $\quad$ Perception } \\
\hline Male & 112 & 3.2500 & 0.7053 & -1.442 & 352 & 0.150 \\
\hline Female & 242 & 3.3636 & 0.6824 & & & \\
\hline \multicolumn{7}{|l|}{ 5. Awareness } \\
\hline Male & 112 & 3.6458 & 0.5337 & -2.238 & 352 & $0.026^{*}$ \\
\hline Female & 242 & 3.7713 & 0.4695 & & & \\
\hline
\end{tabular}

Note: *Significance at $5 \%$

\section{Conclusion}

As the Earth getting older, the minds and abilities of humans undergo some changes to make our lives more comfortable, satisfy basic needs along with humans wants. It encourages people became more futuristic and are always attributed by upgrading and updating technology for more satisfactory living inputs. These developments push human to exhaust the environment with a little sense of being a steward where they tend to have low responsibility on keeping environment clean. Thus, this study sought to determine level of knowledge, practice, attitude, perception and awareness on environmental care among undergraduate students in UiTM Tapah. It discovered that most of students had high level of knowledge, attitude and awareness towards environmental care. However, they had moderate level of practice and perception towards environmental care. In addition, this study concludes that there is difference between male and female regarding to practice, attitude and awareness where female had higher practice, attitude and awareness on environmental care than male students.

\section{Acknowledgement}

The authors would like to thank Universiti Teknologi MARA (UiTM), Tapah Campus for giving an opportunity, a guideline, and provide facilities for this research.

\section{References}

[1] Zulkipli F, Nopiah ZM, Basri NEA, Kie CJ \& Januri SS (2017), Multilinear regression analysis on solid waste generation quantity in Malaysia towards sustainable development. International Journal of Advanced and Applied Sciences 4(9), 46-52.

[2] Zulkipli F, Nopiah, ZM, Basri, NEA \& Kie CJ (2016), Stock flow diagram analysis on solid waste management in Malaysia. AIP Conference Proceedings 1782(1), 1-6. 
[3] Manaf LA, Samah MAA \& Zukki NIM (2009), Municipal solid waste management in Malaysia: Practices and challenges. Waste Management 29(11), 2902-2906.

[4] KPKT (2015), Solid waste management lab 2015 http://www.kpkt.gov.my/resources/index/user_1/Attachments/heba han_slider/slaid_dapatan_makmal.pdf.

[5] SWCorp (2014), Annual report 2013. http://www.swcorp.gov.my/docfile/laporan-tahunan/2014.pdf.

[6] Husin I, Abd Rahim MF, Chenayah S \& Hashim HH (2015), Survey on the perception of community on the cleanliness and environment in Malaysia. Solid Waste Solution Journal, 1.

[7] Ahmad J, Mustafa H, Abd Hamid H \& Abdul Wahab J (2011) Pengetahuan, sikap dan amalan masyarakat Malaysia terhadap isu alam sekitar. Akademika 81(3), 103-115.

[8] Mwiinga F (2014), Perceptions of solid waste management and the role of environmental education among selected residents of Choma Township of Southern Zambia. Master thesis, University of Zambia.

[9] Kollmuss A, \& Agyeman J (2002), Mind the gap: Why do people act environmentally and what are the barriers to prp-environmental behavior? Environmental Education Research 8(3), 239-260.

[10] Tiwi K, Nor AZ \& Tay TP (2006), Penglibatan guru pelatih KPLI Maktab Perguruan Batu Lintang dalam amalan gaya hidup mesra alam. Jurnal Penyelidikan, 7, 1-15.

[11] Ahmad Shah H (2012), Hubungan antara pengetahuan dan motivasi dengan amalan memelihara alam sekitar dalam kalangan guru pelatih (KPLI). Proceedings of the Persidangan Kebangsaan Pembangunan dan Pendidikan Lestari.

[12] Awang Z (2010), Research methodology for business and social science. UiTM Press.

[13] Zulkipli F, Jamian NH, Zulkifli IZ \& Nopiah ZM (2018) Investigating on environmental care towards sustainable solid waste management using exploratory factor analysis at UiTM Tapah campus. Multidisciplinary Informatics Journal 1(1), 1-8. 